\title{
Performance and Puberty of Ram Lambs Produced From Ewes Treated with Arginine \\ Abdel-Khalek, A. E. ${ }^{1}$; W. A. Khalil ${ }^{1}$; T. M. Ashmawy ${ }^{2}$ and Liza A. Abd El-Rafaa ${ }^{2}$ \\ ${ }^{1}$ Animal Production Department, Faculty of Agriculture, Mansoura University, Egypt. \\ ${ }^{2}$ Animal Production Research Institute, Agricultural Research Center, Egypt.
}

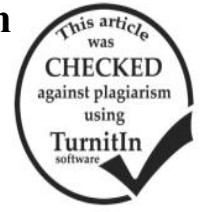

\begin{abstract}
Aim of this study was to investigate performance and puberty of ram lambs produced from pregnant ewes treated with different levels of arginine. This study was carried out at Sakha Animal Production Research Station, belonging to the Animal Production Research Institute in a cooperation with Animal Production Department, Faculty of Agriculture, Mansoura University. During November 2016, total of 45 Ossimi ewes (September mating season), 3-4 years of age and $39.59 \pm 0.15 \mathrm{~kg}$ live body weight (LBW ) were divided into three groups (15 head/each). Ewes in the $1^{\text {st }}$ group (G1) served as a control, ewes in the $2^{\text {nd }}(\mathrm{G} 2)$ and $3^{\text {rd }}(\mathrm{G} 3)$ groups were weekly treated with oral dose of 20 and $30 \mathrm{mg}$ arginine (AR), respectively, for the duration of the treatment from the second month of pregnancy up to lambing. After lambing, total of 8 ram lambs produced from each group were taken and allotted in three groups similar to treatment of their dams. LBW of ram lambs was recorded at birth and monthly up to 12 month of age. In blood plasma of ram lambs, concentration of $\operatorname{IgG}$ and $\operatorname{IgM}$ at 2 days and 1, 3 and $4 \mathrm{wk}$ of age, while concentration of total proteins, albumin, creatinine and glucose, and activity of aspartate (AST) and alanine (ALT) aminotransferase at 2, 4, 6 and 8 month of age were determined. Age and plasma testosterone concentration (PTC) of each ram lambs were determined at three pubertal stages, while semen of $1^{\text {st }}$ ejaculates (at puberty) was evaluated. Results showed that ram lamb LBW was higher $(\mathrm{P}<0.05)$ only in G3 than G1 at birth and at 5 to 12 month of age. Final ram lamb LBW at 12 month of age was higher by 10.2 and $15.9 \%$ in G2 and G3 than in G1, respectively. Plasma concentration of Immunoglobulin $\mathrm{G}(\mathrm{IgG})$ and Immunoglobulin $\mathrm{M}(\mathrm{IgM})$ after 2 days, 1 , 3, and 4 wk of lambing was highest $(\mathrm{P}<0.05)$ in G3, followed by G2, while, G1 showed the lowest values. Plasma concentration of total proteins at 4 month of age and of albumin at 4 and 6 month of age increased $(\mathrm{P}<0.05)$, while glucose decreased $(\mathrm{P}<0.05)$ at 2 and 8 month of age in $\mathrm{G} 2$ and $\mathrm{G} 3$ as compared to those of G1. Creatinine increased $(\mathrm{P}<0.05)$ only in $\mathrm{G} 3$ as compared to $\mathrm{G} 2$ and $\mathrm{G} 1$ at 6 and 8 month of age, while activity of AST and ALT was not affected at all ages. At puberty, age of ram lambs was earlier $(\mathrm{P}<0.05)$ by 51.4 and 33.0 days and $\mathrm{PTC}$ was higher $(\mathrm{P}<0.05)$ by 22.5 and $18.8 \%$ in G2 and G3 than in G1. Ram lambs in G3 showed the best $(\mathrm{P}<0.05)$ semen characteristics of the $1^{\text {st }}$ ejaculation (volume, sperm motility and live sperm output / ejaculate), followed by G2. PTC was higher $(\mathrm{P}<0.05)$ in G2 and G3 than in G1 at 6 and 8 month of age, showing significantly $(\mathrm{P}<0.05)$ an opposite trend at 7 month of age, while insignificantly different at 5,9 and 10 month of age. In conclusion, ram lambs of ewes treated with weekly oral dose of L-arginine-HCL (30 mg / ewe) from the second month of pregnancy up to lambing achieved early age and higher weight at puberty.
\end{abstract}

Keywords: Ram lambs, arginine, puberty, semen, testosterone.

\section{INTRODUCTION}

Quality of nutrition is one of the important reasons that have a direct impact on the productivity of farm animals. In this way, there are some nutrients playing an important role in regulating the growth and immunity (AlDabbas et al., 2008). Supplementation with amino acids (e.g. glutamine, arginine, and $\mathrm{N}$-acetyl-cysteine) improves oxidative defense (Wu et al., 2004) and immune function (Wu and Meininger, 2002) in animals. L-arginine (L-AR) is a nutritionally essential amino acid for several reproductive processes including spermatogenesis in males, and embryonic survival, fetal development and maintenance of vascular tone and hemodynamic (Morris, 2007; Rhoads et al., 2008 and Yao et al., 2008).

Supplementation of L-AR as dietary or intravenous administration has vital role in improvement of reproductive, cardiovascular, pulmonary, kidney, gastrointestinal and liver functions, and immune-response (Wu et al., 2009). L-AR was found to enhance implantation and development of embryos in sheep (Lassala et al., 2011). It has promoting role on physiological activity in the animal body and on the secretion of growth hormone and prolactin and insulin $(\mathrm{Li}$ et al., 2007). It serves as a precursor to nitric oxide (NO) and polyamines (Kwon, 2003). The nitric oxide (NO) produced from L-AR plays an important role in vasodilatation by preventing the adhesion of blood cells and platelets along the endothelial cell layer of blood vessels and inhibiting vascular smooth muscle cell proliferation (Ignarro and Napoli, 2004). So, NO increases blood flow to most organs including those in the reproductive system which increased the transport of metabolites and hormones to organs (Vonnahme et al., 2005). Also, NO has the potential to affect ovarian function (Wu et al., 2013).

In females during gestation period, pregnant animals need more nutrients for growth and development of fetuses. In sheep, AR supplementation during late pregnancy increased lamb birth weight (de Boo et al. 2005 and Zeitoun et al., 2016), survival rate (Lassala et al., 2011 and Zeitoun et al., 2016), improved maternal health (Zeitoun et al., 2016). Similarly, AR supplementation increased the number and litter weight of live-born piglets by 22 and 24\%, respectively (Mateo et al. 2007).

The available information about the effect of AR on puberty or reproductive performance of males is rare. The objective of the current study was to study performance and puberty of ram lambs produced from pregnant ewes treated with different levels of arginine.

\section{MATERIALS AND METHODS}

This study was carried out at Sakha Animal Production Research Station, belonging to the Animal Production Research Institute (APRI) in a cooperation with Animal Production Department, Faculty of Agriculture, Mansoura University, during the period from November 2016 to January, 2018.

Ewes and treatment:

During November 2016, total of 45 Ossimi ewes (September season), having 3-4 years of age and averaged $39.59 \pm 0.15 \mathrm{~kg}$ live body weight (LBW) were divided into three groups (15 head/each) according to their age and live 
body weight were used in this study. Ewes in the $1^{\text {st }}$ group (G1) served as a control group without treatment. However, ewes in the $2^{\text {nd }}(\mathrm{G} 2)$ and $3^{\text {rd }}(\mathrm{G} 3)$ groups were weekly treated with oral dose of 20 and $30 \mathrm{mg}$ arginine, respectively. Ewes were kept under similar management conditions and housed in collective pens. Water and mineral salt were permanently available.

L-arginine-HCl (L-AR-HCl) was purchased from Nutrients Scientific (Diamond Bar, CA, USA) in crystalline powder with $99.6 \%$ purity. Capsules (ARGIPOWER ${ }^{\mathrm{TM}}$ 1500 MEGA Caps ${ }^{\circledR}$ MEGA) containing $1500 \mathrm{mg} /$ capsule of highest-quality pharmaceutical L-AR-HCL. Content of each capsule was dissolved in $750 \mathrm{ml}$ distilled water (2 $\mathrm{mg} / \mathrm{ml}$ ) and stirred, then each ewe in G2 and G3 was weekly treated with oral dose of 10 and $15 \mathrm{ml}$ containing 20 and $30 \mathrm{mg}$ L-AR-HCL / ewe, respectively according to Luther et al. (2008) and Saevre et al. (2011). Each of ARtreated animals was given an oral dose of the designed formula for the duration of the treatment from second month of pregnancy up to lambing.

\section{Experimental lambs groups:}

After lambing, total of 8 ram lambs produced from each control or treated ewes group were taken and allotted in three groups similar to treatment of their dams. Lambs of each group were weighed at birth and monthly during the experimental period from birth up to 12 month of age.

\section{Reproductive performance of lambs:}

Ram lambs in each group were subjected to observation to detect changes in sexual behavior, once at 10 day-interval during the period from 5 month of age till the onset of puberty (first successful ejaculate with motile sperm). To ensure the availability of at least two ewes in estrus at each time of libido test. Ewes were subjected to estrus synchronization by intramuscular injection of $25 \mathrm{mg}$ progesterone (Lutone, Misr Co., for Pharm Ind. SAA, Cairo) for five successive days followed by a signal injection of $5 \mathrm{mg}$ estradiol benzonate (Follone, Misr Co, for Pharm Ind. SAA, Cairo) 24 hours after the last progesterone injection. Treated ewes were subjected to estrus detection 24-48 hours after last hormonal injection using intact ram. Treatment for estrus synchronization was planned at a time suitable for the time of libido test. Age, body weight and plasma testosterone concentration of each ram lamb were determined at $1^{\text {st }}$ mounting, mounting with erection ( $1^{\text {st }}$ penile protrusion) and puberty.

\section{Semen evaluation:}

After the occurrence of puberty (ejaculation), semen was collected by means of an artificial vagina biweekly until 12 months of age. Before ejaculate, ram lambs were sexually stimulated by allowing two false mounts followed by 5 minutes restrain. In the $1^{\text {st }}$ ejaculate, semen volume and initial gross motility of sperm cells (without extension) was estimated on a percentage score basis as described by Melrose and Loing (1970). Also, percentages of live, dead and abnormal spermatozoa as well as sperm cell concentration (Neubauer Haemocytometer) were determined in semen. Sperm output per ejaculate was calculated by multiplying sperm cell concentration by ejaculate volume.

Blood sampling of ewes and their lambs:

Concentration of immunoglobulines (IgG and $\operatorname{IgM}$ ) was determined in blood plasma of ram lambs at 2 days and 1, 3 and $4 \mathrm{wk}$ of age by ELISA (enzyme-linked immune sorbent assay) technique of the Immuno TechBeckman Coulter Company according to Mancini et al. (1965). At 2, 4, 6 and 8 month of age, blood samples were taken from ram lambs of each group for determination of total proteins (Henry, 1964), albumin (Hill and Wells, 1983) and creatinine (King, 1951) concentrations. Glucose concentration was estimated according to the colorimetric method of Sacks (2008). Also, activity of aspartate (AST) and alanine (ALT) aminotransferase were determined spectrophotometrically in blood plasma, on a Helios gamma UV visible spectrophotometer, Thermo spectronic UK. Blood plasma testosterone was quantified by the use of a commercial ELISA kit (HUMAN, Germany) according to Joyce et al. (1977). Intra-assay coefficient of variation was $6.3 \%$.

\section{Statistical analysis:}

Data obtained from this study were statistically analyzed using a software package (SAS, 2004) by one way ANOVA using GLM procedures. Duncan's Multiple Range Test were set at $\mathrm{P}<0.05$ to determine the significant difference according to Duncan (1955). The percentage values were subjected to arcsine transformation before performing the analysis of variances. Means were presented after being recalculated from the transformed value to percentages. Data were expressed as mean \pm standard error.

\section{RESULTS AND DISCUSSION}

\section{Live body weight of ram lambs:}

Live body weight (LBW) of ram lambs significantly $(\mathrm{P}<0.05)$ increased in $\mathrm{G} 3$ as compared to $\mathrm{G} 1$ at birth and at 5 to 12 month of age, but LBW of G2 did not different from that in G1 or G3. However at 1 to 4 month of age, the differences in LBW of lambs among the experimental groups were not significant. It is of interest to note that the effect of AR is dose-dependent, being more pronounced with $\mathrm{AR}$ at 20 than $30 \mathrm{mg} / \mathrm{ewe}$. Generally final LBW of ram lambs in G2 and G3 was higher by about 10.2 and $15.9 \%$ than that of the control group (G1), respectively (Table 1).

Table 1. Effect of arginine treatment of ewes on live body weight $(\mathrm{kg})$ of their ram lams from birth to 12 months of age.

\begin{tabular}{lccc}
\hline $\begin{array}{l}\text { Live body } \\
\text { weight }\end{array}$ & G1 & G2 & G3 \\
\hline At birth & $2.99 \pm 0.27^{\mathrm{b}}$ & $3.56 \pm 0.12^{\mathrm{ab}}$ & $4.02 \pm 0.22^{\mathrm{a}}$ \\
1 month & $4.06 \pm 0.63$ & $5.54 \pm 0.54$ & $5.42 \pm 0.59$ \\
2 month & $8.94 \pm 0.43^{\mathrm{b}}$ & $7.32 \pm 0.94$ & $9.38 \pm 0.52$ \\
3 month & $12.80 \pm 0.38$ & $13.5 \pm 1.03$ & $14.40 \pm 0.54$ \\
4 month & $14.20 \pm 0.51$ & $15.20 \pm 0.98$ & $17.15 \pm 0.50$ \\
5 month & $17.00 \pm 0.66^{\mathrm{b}}$ & $17.70 \pm 1.38^{\mathrm{b}}$ & $19.80 \pm 0.59^{\mathrm{a}}$ \\
6 month & $18.50 \pm 1.03^{\mathrm{b}}$ & $20.70 \pm 1.40^{\mathrm{ab}}$ & $22.30 \pm 0.77^{\mathrm{a}}$ \\
7 month & $22.30 \pm 1.09^{\mathrm{b}}$ & $24.20 \pm 1.53^{\mathrm{ab}}$ & $27.10 \pm 0.91^{\mathrm{a}}$ \\
8 month & $24.40 \pm 1.04^{\mathrm{b}}$ & $27.60 \pm 2.05^{\mathrm{ab}}$ & $30.10 \pm 0.84^{\mathrm{a}}$ \\
9 month & $26.10 \pm 0.94^{\mathrm{b}}$ & $30.20 \pm 1.83^{\mathrm{ab}}$ & $34.90 \pm 1.49^{\mathrm{a}}$ \\
10 month & $28.80 \pm 1.21^{\mathrm{b}}$ & $33.50 \pm 1.83^{\mathrm{ab}}$ & $36.00 \pm 1.43^{\mathrm{a}}$ \\
11 month & $30.30 \pm 1.13^{\mathrm{b}}$ & $35.40 \pm 1.64^{\mathrm{ab}}$ & $38.60 \pm 1.43^{\mathrm{a}}$ \\
12 month & $33.20 \pm 1.12^{\mathrm{b}}$ & $36.80 \pm 1.57^{\mathrm{ab}}$ & $40.80 \pm 1.32^{\mathrm{a}}$ \\
\hline
\end{tabular}

a, and b: Means denoted within the same row with different superscripts are significantly different at $\mathbf{P}<0.05$. 
In accordance with the present results, Zeitoun et al. (2016) found that lamb birth weight of Najdi pregnant ewes treated with L-AR ( $75 \mathrm{mg} / \mathrm{kg} / \mathrm{head} /$ day) at first $56 \mathrm{~d}$ of pregnancy increased as compared to those treated with high L-AR level $(150 \mathrm{mg} / \mathrm{kg} / \mathrm{head} / \mathrm{day})$. Treatment of ewes with AR from day 100-121 of pregnancy increased birth weights of lambs born from mothers carrying multiple fetuses by about 23\% (Lassala et al. 2011). In pig, dietary supplementation $(0.83 \%$ AR) between 90 and 114 days of pregnancy increased average LBW of live-born piglets at birth by $16 \%$ (Wu et al., 2012).

Uterine capacity is a major factor limiting fetal survival and growth in sheep as demonstrated by the inverse relationship between fetal number and birth weight (Gootwine et al., 2007). Also, placental size, function and utero-placental transfer of materials between dam and fetus were the major factors to affect growth and development of the fetus (Gude et al., 2004 and Wu et al., 2006, 2010). A crucial factor for survival, growth, and development of fetus is a functional placenta for transporting nutrients, respiratory gases, and metabolism products between the maternal and fetal circulations (Wang et al. 2012). AR is a nutritionally essential amino acid for the fetus and is a precursor for the synthesis of nitric oxide and polyamines, which are essential for placental growth and function, and growth of new vessels from the existing vasculature and, therefore, for increasing uterine and placental-fetal blood flow (Wu et al., 2004 and 2009; Lassala et al., 2010 and 2011 and McCoard et al., 2013). Polyamines play important roles in placental health and development by regulating angiogenesis or new blood vessels formation (Kwon, 2003). These physiological processes are critical for growth and development of fetuses (Wu et al., 2004 and 2008). In addition, AR treatment during pregnancy could result in changes in hormonal secretions, which may affect fetal and maternal metabolism (Chew et al., 1984 and Kensinger et al., 1986).

\section{Immuno response:}

\section{Blood immunoglobulines of ram lambs:}

Ram lambs in G3 showed significantly $(\mathrm{P}<0.05)$ the highest immune response, in terms of the highest plasma concentration of immunoglobulines (IgG and IgM) at all studied ages (after 2 day, 1, 3, and 4 wk of lambing), followed by those of G2, while, control ram lambs (G1) showed significantly $(\mathrm{P}<0.05)$ the lowest $\operatorname{IgG}$ and $\operatorname{IgM}$ concentrations at all ages. It is of interest to note that IgG and $\operatorname{IgM}$ concentrations in all groups showed the maximum levels on day 2 post-lambing, and then markedly decreased by advancing lamb age, particularly after one week of age (Table 2).

Table 2. Effect of arginine treatment of ewes on IgG and IgM concentration in blood plasma of their ram lambs at different ages (week).

\begin{tabular}{|c|c|c|c|}
\hline Age & G1 (control) & G2 & G3 \\
\hline \multicolumn{4}{|c|}{ Concentration of IgG (mg/dl) in blood plasma: } \\
\hline $0 \mathrm{wk}$ & $52.16 \pm 1.19^{\mathrm{b}}$ & $52.57 \pm 0.87^{\mathrm{b}}$ & $57.77 \pm 0.77^{\mathrm{a}}$ \\
\hline $1 \mathrm{wk}$ & $42.64 \pm 1.34^{\mathrm{c}}$ & $48.90 \pm 1.87^{\mathrm{b}}$ & $57.36 \pm 0.95^{\mathrm{a}}$ \\
\hline $3 \mathrm{wk}$ & $28.79 \pm 1.27^{\mathrm{b}}$ & $31.74 \pm 0.87^{\mathrm{ab}}$ & $33.77 \pm 1.38^{\mathrm{a}}$ \\
\hline $4 \mathrm{wk}$ & $23.78 \pm 0.97^{\mathrm{b}}$ & $28.81 \pm 1.22^{\mathrm{a}}$ & $29.28 \pm 1.13^{\mathrm{a}}$ \\
\hline \multicolumn{4}{|c|}{ Concentration of IgM (mg/dl) in blood plasma: } \\
\hline $0 \mathrm{wk}$ & $1.83 \pm 0.16^{\mathrm{b}}$ & $2.51 \pm 0.23^{\mathrm{a}}$ & $2.60 \pm 0.08^{\mathrm{a}}$ \\
\hline $1 \mathrm{wk}$ & $1.16 \pm 0.03^{\mathrm{b}}$ & $1.62 \pm 0.02^{\mathrm{b}}$ & $2.68 \pm 0.17^{\mathrm{a}}$ \\
\hline $3 \mathrm{wk}$ & $1.13 \pm 0.05^{\mathrm{b}}$ & $1.54 \pm 0.03^{\mathrm{a}}$ & $1.61 \pm 0.13^{\mathrm{a}}$ \\
\hline $4 \mathrm{wk}$ & $1.04 \pm 0.06^{\mathrm{b}}$ & $1.61 \pm 0.03^{\mathrm{a}}$ & $1.60 \pm 0.09^{\mathrm{a}}$ \\
\hline
\end{tabular}

a, $b$ and c: Means denoted within the same row with different superscripts are significantly different at $P<0.05$.

0 wk: 2 days after lambing.

According to Barta (1993), concentration of IgG in blood serum at birth steeply increases in lambs after colostrum intake until the second day to the maximum value, and then it decreases until 16 days of age. This decrease continues until the minimum value at 60 days of age. In the subsequent period until 180 days of age, a recurrent increase occurred, but at value does not reach the level of adult individuals. The syndesmochorial placenta of ruminants does not allow the transfer of high-molecularweight proteins. Ruminants suffer from a gammaglobulinaemia immediately after birth before the first intake of colostrum (Aldridge et al., 1992). This is in accordance with the present results during 2 weeks postlambing. On the other hand, Maden et al. (2003) observed that IgG concentration in the blood serum dropped on day 1 post partum as compared to at parturition, then increased again on day 15 post partum.

Blood parameters:

Blood biochemicals and enzyme activity:

Ram lambs of treatment ewe groups (G2 and G3) significantly $(\mathrm{P}<0.05)$ increased only plasma concentration of total proteins at 4 month of age and of albumin at 4 and 6 month of age, while significantly $(\mathrm{P}<0.05)$ decreased plasma glucose concentration at 2 and 8 month of age as compared to those of G1. Only ram lambs of G3 significantly $(\mathrm{P}<0.05)$ increased plasma creatinine concentration at 6 and 8 month of age. However, treatment had insignificant effect on plasma enzyme activity (AST and ALT) at all ages studied (Table 3).

Concentrations of blood total proteins and globulin can be used as an indicator for monitoring passive transfer and estimating the amount of circulating IgG in newborns. In addition, total proteins concentration in blood and colostrum are important for lamb growth (O'Brien and Sherman, 1993). Increasing albumin level, which represents about 35 and $50 \%$ of total proteins (Kaneko, 1997), and subsequently increasing total proteins level in ram lambs of treatment groups (G2 and G3), significantly at 4 and 6 month of age and insignificantly at other ages, indicated high liver function and good healthy status of these lambs. These results could be in consistent with the $1^{\text {st }}$ intake of colostrum immediately after lambing during 
the first hours of life of lambs (Piccione et al., 2009). This finding indicated the tendency of high concentration of total proteins and albumin in blood plasma of lambs of treatment groups (G2 and G3) as a result of increasing plasma immunoglobulin levels (Baranowski et al., 2000). Piccione et al. (2012) observed that the total blood proteins levels were significantly affected by the physiological period and increased during Lactation. This may reflect the maternal needs of proteins for milk production and providing immunoglobulin (Bell et al., 2000; Mohri et al., 2007).

In sheep, entry rate of glucose was reported to positively correlate with energy supply level (Landau, 1994). At late pregnancy, Landau (1994) found positive correlation between lamb birth weight and glucose entry rate of their mothers. Also, availability of colostrum to new-born lambs was affected by glucose entry rate (Barry and Manley, 1985). These finding may reflect the highest LBW of lambs in treatment groups as compared to control group.

Creatinine level is considered as an indicator of glomerular filtration rat in the kidney. The present

creatinine levels of lambs in all groups are within the normal range (Keenan and Allardyce, 1986), indicating normal kidney function of ram lambs in treatment and control groups. It is of interest to note that to note that increasing creatinine level in lambs of G3 was attributed to higher protein utilization of lambs in this group, reflecting the highest live body weight from 5 up to 12 month of age (Table 1).

Activity AST has some relations with liver and heart functions in cows (Kaneko et al., 2008), and it is one of the common indicators of liver failure (Sattler and Fürll, 2004). However, ALT activity is important for protein catabolism by catalyzing alanine and alpha ketoglutarate and transfer them into generates pyruvate and glutamate (Ray et al., 2008). The obtained insignificant differences among the experimental groups at all ages studied in plasma aminotransferases activities, being within the normal ranges, may reflect intact structure of body animal cells and normal liver function (Milinković-Tur et al., 2005).

Table 3. Effect of arginine treatment on blood plasma biochemicals and enzyme activity in blood serum of ram lambs at different ages (wk).

\begin{tabular}{|c|c|c|c|}
\hline Item & G1 (control) & G2 & G3 \\
\hline \multicolumn{4}{|l|}{ Total proteins $(\mathrm{g} / \mathrm{dl})$ : } \\
\hline 2 mo of age & $6.99 \pm 0.71$ & $7.68 \pm 1.21$ & $7.74 \pm 1.22$ \\
\hline 4 mo of age & $6.50 \pm 0.47^{b}$ & $7.14 \pm 0.14^{\mathrm{a}}$ & $7.20 \pm 0.25^{\mathrm{a}}$ \\
\hline 6 mo of age & $6.20 \pm 0.41$ & $6.64 \pm 0.61$ & $7.15 \pm 0.42$ \\
\hline 8 mo of age & $5.93 \pm 1.57^{b}$ & $6.68 \pm 0.31^{\mathrm{ab}}$ & $6.65 \pm 0.57^{\mathrm{a}}$ \\
\hline \multicolumn{4}{|l|}{ Albumin (g/dl): } \\
\hline 2 mo of age & $3.60 \pm 0.42^{\mathrm{b}}$ & $4.22 \pm 0.10^{\mathrm{a}}$ & $4.41 \pm 0.36^{\mathrm{a}}$ \\
\hline 4 mo of age & $3.10 \pm 0.47^{b}$ & $4.16 \pm 0.26^{\mathrm{a}}$ & $4.22 \pm 0.08^{\mathrm{a}}$ \\
\hline 6 mo of age & $3.02 \pm 0.51^{\mathrm{b}}$ & $4.07 \pm 0.57^{\mathrm{a}}$ & $3.92 \pm 0.50^{\mathrm{a}}$ \\
\hline 8 mo of age & $3.92 \pm 0.44$ & $3.83 \pm 0.73$ & $3.80 \pm 0.42$ \\
\hline \multicolumn{4}{|l|}{ Glucose (mg/dl): } \\
\hline 2 mo of age & $105.33 \pm 5.23^{\mathrm{a}}$ & $86.88 \pm 5.76^{\mathrm{b}}$ & $85.88 \pm 4.38^{\mathrm{b}}$ \\
\hline 4 mo of age & $94.44 \pm 0.29^{\mathrm{a}}$ & $85.77 \pm 10.03^{b}$ & $84.11 \pm 5.42^{b}$ \\
\hline $6 \mathrm{mo}$ of age & $92.77 \pm 3.89^{c}$ & $99.33 \pm 11.75^{b}$ & $103.8 \pm 5.89^{\mathrm{a}}$ \\
\hline 8 mo of age & $127.7 \pm 4.19^{\mathrm{a}}$ & $111.3 \pm 3.89^{b}$ & $110.8 \pm 2.74^{\mathrm{b}}$ \\
\hline \multicolumn{4}{|l|}{ Creatinine (mg/dl): } \\
\hline 2 mo of age & $0.47 \pm 0.04$ & $0.35 \pm 0.15$ & $0.56 \pm 0.04$ \\
\hline 4 mo of age & $0.91 \pm 0.20$ & $0.99 \pm 0.10$ & $0.99 \pm 0.09$ \\
\hline 6 mo of age & $0.94 \pm 0.17^{\mathrm{b}}$ & $0.82 \pm 0.00^{\mathrm{b}}$ & $1.21 \pm 0.24^{\mathrm{a}}$ \\
\hline $8 \mathrm{mo}$ of age & $0.84 \pm 0.05^{\mathrm{b}}$ & $0.94 \pm 0.09^{\mathrm{ab}}$ & $1.10 \pm 0.08^{\mathrm{a}}$ \\
\hline \multicolumn{4}{|l|}{ AST (U/l): } \\
\hline 2 mo of age & $70.86 \pm 5.12^{\mathrm{a}}$ & $62.06 \pm 5.22^{\mathrm{b}}$ & $58.00 \pm 0.74^{b}$ \\
\hline 4 mo of age & $59.56 \pm 1.26^{\mathrm{c}}$ & $72.50 \pm 2.49^{\mathrm{a}}$ & $68.30 \pm 2.53^{b}$ \\
\hline $6 \mathrm{mo}$ of age & $66.83 \pm 3.40^{\mathrm{a}}$ & $57.40 \pm 3.78^{\mathrm{b}}$ & $60.83 \pm 2.53^{b}$ \\
\hline $8 \mathrm{mo}$ of age & $70.10 \pm 3.14^{b}$ & $64.80 \pm 3.90^{\mathrm{c}}$ & $84.10 \pm 3.63^{\mathrm{a}}$ \\
\hline \multicolumn{4}{|l|}{ ALT (U/l): } \\
\hline 2 mo of age & $17.50 \pm 0.50^{\mathrm{ab}}$ & $18.50 \pm 2.38^{\mathrm{a}}$ & $15.00 \pm 1.50^{\mathrm{b}}$ \\
\hline $4 \mathrm{mo}$ of age & $19.50 \pm 3.96$ & $17.00 \pm 3.27$ & $16.50 \pm 5.26$ \\
\hline 6 mo of age & $17.00 \pm 1.32$ & $17.00 \pm 3.50$ & $16.00 \pm 4.27$ \\
\hline 8 mo of age & $25.93 \pm 2.71$ & $26.00 \pm 2.00$ & $23.00 \pm 0.50$ \\
\hline
\end{tabular}

a, $b$ and c: Means denoted within the same row with different superscripts are significantly different at $P<0.05$.

\section{Puberty stages:}

Reproductive performance of ram lambs in the experimental groups, in terms of age and plasma testosterone concentration was studied and compared at three main pubertal stages (Table 4$)$. At the $1^{\text {st }}$ stage $\left(1^{\text {st }}\right.$ mounting), age of ram lambs was significantly $(\mathrm{P}<0.05)$ the earliest in G2 and the latest in G3, but did not differ in G3 from that in G1 and G3, but the differences in plasma testosterone concentration were not significant among the experimental groups.

At the $2^{\text {nd }}$ stage $\left(1^{\text {st }}\right.$ mounting with erection), age was significantly $(\mathrm{P}<0.05)$ earlier and plasma testosterone concentration was higher in G2 and G3 than in G1, being the earliest and highest in ram lambs in G2 (Table 4).

The same trend was observed at the $3^{\text {rd }}$ stage $\left(1^{\text {st }}\right.$ ejaculation, puberty), whereas age of ram lambs was 
significantly $(\mathrm{P}<0.05)$ earlier by 51.4 and 33.0 days and plasma testosterone concentration was significantly $(\mathrm{P}<0.05)$ higher by 22.5 and $18.8 \%$ in $\mathrm{G} 2$ and $\mathrm{G} 3$ than in G1 (control). It is worthy noting that testosterone level showed marked development in all groups by advancing pubertal stage, particularly from the $2^{\text {nd }}$ stage to $3^{\text {rd }}$ stage (puberty, Table 4).

Table 4. Effect of arginine treatment of ewes on age and plasma testosterone concentration of their ram lambs at different pubertal stages.

\begin{tabular}{lcccc}
\hline Pubertal stage & Item & G1 (control) & G2 & G3 \\
\hline \multirow{2}{*}{$1^{\text {st }}$ mounting } & Age (day) & $172.4 \pm 2.23^{\mathrm{a}}$ & $150.3 \pm 1.13^{\mathrm{b}}$ & $162.1 \pm 1.06^{\mathrm{ab}}$ \\
& LBW (kg) & 18.43 & 17.70 & 19.80 \\
$1^{\mathrm{st}}$ mounting with erection & Testosterone (ng/ml) & $1.15 \pm 0.06$ & $1.13 \pm 0.03$ & $1.03 \pm 0.02$ \\
& Age (day) & $224.8 \pm 1.98^{\mathrm{a}}$ & $182.3 \pm 0.98^{\mathrm{b}}$ & $191.4 \pm 1.22^{\mathrm{b}}$ \\
& LBW (kg) & 23.50 & 20.60 & 22.40 \\
& Testosterone (ng/ml) & $1.53 \pm 0.01^{\mathrm{b}}$ & $2.15 \pm 0.03^{\mathrm{a}}$ & $2.21 \pm 0.04^{\mathrm{a}}$ \\
$1^{\mathrm{st}}$ ejaculation (puberty) & Age (day) & $274.8 \pm 1.15^{\mathrm{a}}$ & $223.4 \pm 1.03^{\mathrm{b}}$ & $241.8 \pm 1.11^{\mathrm{b}}$ \\
& LBW (kg) & 26.10 & 24.80 & 29.89 \\
& Testosterone (ng/ml) & $2.71 \pm 0.02^{\mathrm{b}}$ & $3.32 \pm 0.04^{\mathrm{a}}$ & $3.22 \pm 0.01^{\mathrm{a}}$ \\
\hline
\end{tabular}

a and b: Means denoted within the same row with different superscripts are significantly different at $P<0.05$.

In agreement with the obtained results, feed ration supplemented with 0.2 gm protected AR / $\mathrm{kg}$ body weight to pre-pubertal Hebsi male goat kids resulted in earlier age at puberty than in controls, probably through the indirect effect of $\mathrm{AR}$ on testosterone secretion and consequently spermatogenesis (Basiouni, 2010).

\section{Physical semen characteristics of the $1^{\text {st }}$ ejaculation:}

Ram lambs in G3 showed significantly $(\mathrm{P}<0.05)$ the best semen characteristics of the $1^{\text {st }}$ ejaculation, in terms of the highest ejaculate volume, sperm motility percentage and live sperm output per ejaculate. However, ram lambs in $\mathrm{G} 2$ showed significantly $(\mathrm{P}<0.05)$ higher ejaculate volume only than in G1, while live sperm output/ejaculate did not differ from that in G3 and G1. On the other hand, the differences in percentage of live and abnormal sperm cells, and sperm cell concentration were not significant among the experimental groups (Table 5).

It is expected that these starting values will increase and reach normally by the advance of age and consequently the complete development of the sex organs. It is believed that any comparison at such early stage might be meaningless due to the quick change in the values of the characters and the variability of body weight between tested groups at puberty. However, the value of first ejaculate in this study was used as a sign to indicate that animals reached puberty.

Table 5. Effect of arginine treatment on semen characteristics of ram lambs in the experimental groups.

\begin{tabular}{lccc}
\hline Pubertal stage & G1 (control) & G2 & G3 \\
\hline Ejaculate volume (ml) & $0.21 \pm 0.01^{\mathrm{b}}$ & $0.32 \pm 0.01^{\mathrm{a}}$ & $0.36 \pm 0.02^{\mathrm{a}}$ \\
Sperm motility (\%) & $45.5 \pm 2.15^{\mathrm{b}}$ & $45.4 \pm 1.98^{\mathrm{b}}$ & $50.6 \pm 1.66^{\mathrm{a}}$ \\
Live sperm (\%) & $41.9 \pm 1.89$ & $41.8 \pm 1.46$ & $44.6 \pm 1.23$ \\
Abnormal sperm (\%) & $18.1 \pm 1.78$ & $16.7 \pm 1.13$ & $17.3 \pm 1.02$ \\
Sperm concentration $\left(\times 10^{9} / \mathrm{ml}\right)$ & $1.01 \pm 0.06$ & $1.15 \pm 0.04$ & $1.07 \pm 0.04$ \\
Live normal sperm output $\left(\mathrm{x} 10^{9} /\right.$ jec.) & $0.404 \pm 0.03^{\mathrm{b}}$ & $0.689 \pm 0.06^{\mathrm{ab}}$ & $0.869 \pm 0.04^{\mathrm{a}}$ \\
\hline
\end{tabular}

a, and b: Means denoted within the same row with different superscripts are significantly different at $P<0.05$.

The results obtained concerning the semen quality at first ejaculate (puberty) are in agreement with the results of El-Shamaa (2002), who found that semen quality at puberty were low and reach normality by the advance of age and consequently the complete development of the sex organs. In this respect, several authors reached to marked improvement in ejaculate volume with age progress (ElSaidy et al., 2004).

Despite the observed reduction in ejaculate volume, Rege et al. (2000) reported a gradual improvement in ejaculate volume of ram lambs by advancing age. The earlier ejaculation with the highest ejaculate volume of ram lambs in treatment groups (G2 and G3) may indicate the beneficial effects of ewe treatment with $\mathrm{AR}$ on growth performance and consequently on the accessory sex glands to produce large volume of the seminal plasma and/or attributed to the significantly $(\mathrm{P}<0.05)$ increase in testosterone level in blood plasma of ram lambs. The accessory glands are functionally controlled by testosterone (Martin et al., 1994).

The observed improvement in sperm motility of ram lambs at puberty in G3 as compared to that in G2 or G1 was reported by Hassanpour et al. (2007), found that the effects of L-AR on sperm motility are dose-dependent. Some authors recorded a correlation between AR deficiency and decrease in sperm motility (Jungling and Bunge, 1976; Polakoski et al., 1976). L-AR plays a key role in modulating the host's defense and cellular immunity. L-AR administration resulted in an improvement in sperm motility of oligospermic and asthenospermic patients without any side effects (Aydin et al.; 1995). Also, AR plays a vital role in the maintenance of sperm motility and sperm metabolism within the reproductive tract or throughout storage under in vitro conditions (Mann and Lutwak-Mann, 1981). Moreover, AR stimulates in vitro sperm motility in different species (Patel et al., 1998; Srivastava et al., 2006). Generally, the reported increase in sperm motility percentage at mature than at puberty age was attributed to contentious development in testicular and epididymal tissues (PerezClaring et al., 1998).

L-AR plays a key role in modulating the host's defense and cellular immunity. In this line, Aydin et al. (1995) observed that sperm count increased in oligospermic and asthenospermic patients treated with LAR. Generally, AR takes part in spermatogenesis and 
considered as a basic component of the nucleoprotein of sperm cells in several animal species (Adnan, 1970). Also, AR prevents bi-layer phospholipids membrane peroxidation under various peroxidation situations through production of NO to protect integrity of structure and function of sperm cells (Srivastava et al., 2006).

Blood plasma testosterone concentration (ng/ml):

Results illustrated in figure (1) revealed that testosterone concentration of ram lambs was significantly $(\mathrm{P}<0.05)$ higher in $\mathrm{G} 2$ and $\mathrm{G} 3$ than in $\mathrm{G} 1$ at 6 and 8 month of age, showing significantly $(\mathrm{P}<0.05)$ an opposite trend at 7 month of age, while insignificantly different at 5, 9 and 10 month of age. These trends cleared testosterone spikes prior to puberty during the $6^{\text {th }}$ month in treatment groups and during the $7^{\text {th }}$ month in control one, being earlier in treatments than in control group.

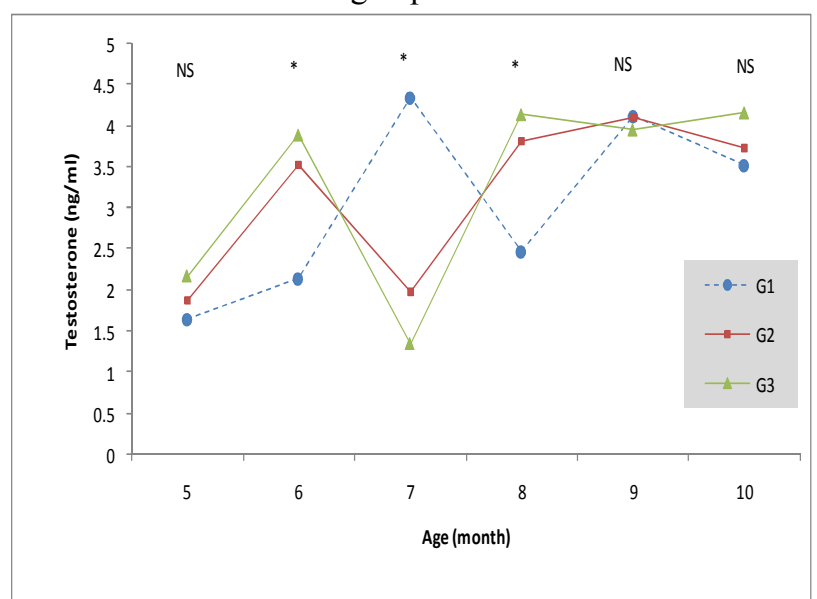

Fig. 1. Change in plasma testosterone concentration (ng/ml) of ram lambs in different experimental groups at pre- and post-pubertal ages.

In accordance with the present results, Basiouni (2010) found that testosterone concentration significantly increased in male goat kids fed ration containing $0.2 \mathrm{gm}$ protected AR / $\mathrm{kg}$ body weight/day as they approach the age of puberty compared to control (3.15 vs. $1.10 \mathrm{ng} / \mathrm{ml})$. Puberty is associated with a marked increase in testosterone concentration (Chakraborty et al., 1989), which affect the development of the male accessory sex glands, sexual behavior stimulation and spermatogenesis (Hafez and Hafez, 2000). It is well known that testosterone is under the indirect regulation of the anterior pituitary gland LH secretion (Bearden and Fuquay, 1992) and AR treatment in pre-pubertal female sheep, goats and hens was found to increase the rate of LH secretion (Basiouni, 2009). Finally, AR was found to stimulate the release of $\mathrm{GH}$ hormone and insulin-like growth factor (Davenport et al., 1995), GnRH and LH (Basiouni, 2009).

\section{CONCLUSION}

In conclusion, weekly treatment of ewes with Larginine-HCL at a level of $30 \mathrm{mg}$ in $15 \mathrm{ml}$ distilled water as an oral dose during the period from second month of pregnancy up to lambing showed impact on their ram lambs regarding incidence of puberty at early age with appropriate live body weight, sexual desire, and semen characteristics, which may be beneficial for raising breeding rams for natural mating and artificial insemination in sheep farms.

\section{REFERENCES}

Adnan, M. (1970). Effect of arginine on oligospermia. Fertil Steril, 21: 217-219.

AL-Dabbas, F. M. ; A. H. Hamra and F. T. Awawdeh (2008). The effect of arginine supplementation on some blood parameters, ovulation rate and concentration of estrogen and progesterone in female Awassi sheep. Pakistan J. Biol. Sc. 11(20): 23892394.

Aldridge B. ; F. Garry and R. Adams (1992). Role of colostral transfer in neonatal calf management: failure of acquisition of passive immunity. Compendium and Continuing Education for the Practising Veterinary, 14: 265-270.

Aydin, S.;O.Inci and B. Alagöl (1995). The role of arginine, indomethacin and kallikrein in the treatment of oligoasthenospermia. Int. Urol. Nephrol.,27:199-202.

Baranowski, P. ; S. Baranow-Baranowski and W. Klata (2000). Some hematological and biochemical serum and bone tissue indices of lambs derived from ewes fed on vitamin- and mineral- vitamin supplements during pregnancy. Bull. Vet. Inst. Pulawy., 44: 204 214.

Barry, T. N. and T. R. Manley (1985). Glucose and protein metabolism during late pregnancy in triplet-bearing ewes given fresh forage ad libitum. Brit. Nutr., 54: 521-533.

Barta, O. (1993). Radial immunodiffusion quantitative determination of immunoglobulins and C3. Monographs in Animal Immunology, 2: 3-14.

Basiouni, G. F. (2009). The effect of feeding an extra amounts of arginine to Local Saudi Hens on luteinizing hormone secretion. J. Biol. Sci. 9(6):617620.

Basiouni, G. F. (2010). Effect of protected arginine supplementation on age, semen quality and testosterone concentrations at puberty in Hebsi male goat kids. Met., Env. \& Arid Land Agric. Sci., Vol. 21(2): 19-27.

Bearden, H. J. and W. Fuquay (1992). Applied Animal Reproduction. Prentice Hall England Cliffs, New Jersey.

Bell, A.W. ; W.S. Burhans and T. R. Overton (2000). Protein nutrition in late pregnancy, maternal protein reserves and lactation performance in dairy cows. Proc. Nutr. Soc. 59:119-126.

Chakraborty, P. K. ; L. D. Stuart and J. L. Brown (1989). Puberty in the male Nubian goat: Serum concentrations of LH, FSH and testosterone from birth through puberty and semen characteristics at sexual maturity. Anim. Reprod. Sci. 20, 91-101.

Chew, B. P. ; J. R. Eisenman and T. S. Tanaka (1984). Arginine infusion stimulates prolactin, growth hormone, insuline and subsequent lactation in pregnant dairy cows. J. Dairy Sci. 67: 2507.

Davenport, M. ; C. Brain ; C. Vandenberg ; S. Zappala ; P. Duffy ; P. G. Ransley and D. Grant (1995). The use of the hCG stimulation test in the endocrine evaluation of cryptorchidism. Br. J. Urol. 76:790794.

De Boo, H. A. ; P. L. van Zijl ; D. E. Smith ; W. Kulik ; H. N. Lafeber and J. E. Harding (2005). Arginine and mixed amino acids increase protein accretion in the growth-restricted and normal ovine fetus by different mechanisms. Pediatr. Res. 58:270-277.

Duncan, D. B. (1955). Multiple range and multiple F-tests. Biometrics, 11:1-42. 
El-Saidy, B. E. (2004). Seasonal variations in the reproductive performance of crossbred Finnish rams (Finnish x Rahmani) in Egypt. Alex. J. Agric. Res. 49(1): 11.

El-Shamaa, I. S. (2002). Onset of puberty, semen production and blood constituents in crossbred male lambs as affected by dietary yeast culture addition. J. Agric. Sci. Mansoura Univ. 27(7): 4589.

Gootwine, E.; T. E. Spencer and F. W. Bazer (2007). Littersize-dependent intrauterine growth restriction in sheep. Animal 1(4):547-564.

Gude, N. M. ; C. T. Roberts ; B. Kalionis and R. G. King (2004). Growth and function of the normal human placenta. Thromb. Res. 114: 397-407.

Hafez, B. and E. S. E. Hafez (2000). Reproduction in Farm Animals. Lippincott, Williams \& Wilkins, USA.

Hassanpour, H. ; P. Mirshokrai ; A. Shirazi and A. Aminian (2007). Effect of nitric oxide on ram sperm motility in vitro. Pak. J. Biol. Sci., 10 : 2374 -2378.

Henry, R. J. (1964). Clinical Chemistry: Principles and Techniques. Harper and Raw, New York, USA, p.747.

Hill, P.G. and T. N. Wells (1983). Ann. Clin. Biochem. 20: 264-270

Ignarro, L. J. and C. Napoli (2004). Novel features on nitric oxide, endothelial nitric oxide synthase and atherosclerosis. Curr. Atheroscler. Rep., 6: 278-287.

Joyce, B. G. ; G. F. Read and D. R. Fahrny (1977). A specific enzyme immunoassay for progesterone in human plasma. Steroids, 29:761-769.

Jungling, M. L. and R. G. Bunge (1976). The treatment of spermatogenic arrest with arginine. Fertil. Steril., 27: 282-283.

Kaneko, J. J. ; W. Harvey and M. L. Bruss (1997). Clinical Biochemistry of Domestic Animals. $5^{\text {th }}$ edition Academic Press, San Diego, London, Boston, New York, Sydney, Tokyo, Toronto. Apendix VIII: Blood analyse reference values in large animals. pp. 890894.

Kaneko, J. J. ; J. W. Harvey and M. L. Bruss (2008). Clinical Biochemistry of Domestic Animals. $6^{\text {th }}$ Ed. Elsevier Academic, Amsterdam, pp:356-365.

Keenan, D. M. and C. J. Allardyce (1986). Changes of plasma creatinine levels of sheep during sub maintenance feeding. In: Aust. Vet. J., 63: 29-30.

Kensinger, R.S. ; R. J. Collier and F. W. Bazer (1986) Effect of number of conceptuses on maternal hormone concentrations in the pig. J. Anim. Sci. 62:1666-1674.

King, E. J. (1951). Micro-analysis in Medical Biochemistry, $2^{\text {nd }}$ ed. London: J. and A. Churchill.

Kwon, H. ; T. E. Spencer and F. W. Bazer (2003). Developmental changes of amino acids in ovine fetal fluids. Biol. Reprod. 68: 1813-1820.

Landau, S. (1994). Increasing glucose metabolism in dry and pregnant ewes by nutritional means. Ph.D. Thesis, The Hebrew University of Jerusalem, Israel.

Lassala, A. ; F. W. Bazer ; T. A. Cudd ; S. Datta ; D. H. Keisler; M. C. Satterfield; T. E. Spencer and G. Wu (2011). Parenteral administration of L-Arginine enhances fetal survival and growth in sheep carrying multiple fetuses. The Journal of Nutrition, 141:849855

Lassala, A. ; F. W. Bazer and T. A. Cudd (2010). Parenteral administration of L-arginine prevents fetal growth restriction in undernourished ewes. J. Nutr. 140:1242-1248.

Li, Y. ; X. Yu ; S. ; Lin ; X. Li ; S. Zhang and Y. H. Song (2007). Insulin-like growth factor-1 enhances the migratory capacity of mesenchymal stem cells Biochem. Biophys. Res. Commun., 356(3):780-784.
Luther, J. S. ; E. J. Windorski ; C. S. Schauer ; J. D. Kirsch ; K. A. Vonnahme ; L. P. Reynolds ; J. S. Caton and $\mathrm{G}$. $\mathrm{Wu}$ (2008). Impacts of L-arginine on ovarian function and reproductive performance in ewes. J. Anim. Sci. 86 (2): 586-593

Maden, M. ; V. Altumok ; F. M. Birdane ; V. Asla and M. Nizamlioglu (2003). Blood and colostrums / milk serum $\gamma$-glutamyl transferase activity as a predictor of passive transfer status in lambs. J. Vet. Med. 50:128 131.

Mancini, G. ; A. O. Carbonara and J. F. Heremans (1965). Immunochemical quantitation of antigens by single radial immunodiffusion. Immuno-chemistry, 2, 235.

Mann, T. and C. Lutwak-Mann (1981). Male Reproductive Function and Semen. Springer-Verlag, Berlin.

Martin, G. B. ; S. Tjondronegoro and M. A. Blackberry (1994). Effects of nutrition on testicular size and the concentrations of gonadotrophins testosterone and inhibin in plasma of mature male sheep. J. Reprod. Fertl. 101: 121-130.

Mateo, R. D. ; G. Wu and F. W. Bazer (2007). Dietary Larginine supplementation enhances the reproductive performance of gilts. J. Nutr. 137: 652-656.

McCoard, S. A. ; F. Sales ; N. Wards ; Q. Sciascia ; M. Oliver ; J. Koolaard and D. S. van der Linden (2013). Parenteral administration of twin-bearing ewes with l-arginine enhances the birth weight and brown fat stores in sheep. Springer Plus, 2:684.

Melrose, D. R. and J. A. Laing (1970). The characteristics of normal semen. Chap. 4, Fertility and infertility in the domestic animals. Ed. By J. A. Laing Bailliere Tindall and Gassell, London.

Milinković-Tur, S.; V. Perić ; Z. Stojević ; M. Zdelar-Tuk and J. Piršljin (2005): Concentrations of total proteins and albumins, and AST, ALT and GGT activities in the blood plasma of mares during pregnancy and early lactation. Vet. Arhiv, 75: 195-202.

Mohri, M. ; K. Sharifi and S. Eidi (2007). Hematology and serum biochemistry of Holstein dairy calves: age related changes and comparison with blood composition in adults. Research in Veterinary Science, 83:30-39.

Morris Jr., S. M. (2007) Arginine Metabolism: Boundaries of Our Knowledge. The Journal of Nutrition, 137: 1602-1609.

O'brien, J. P. and D. M. Sherman (1993). Serum immunoglobulin concentrations of newborn goat kids and subsequent kid survival through weaning, Small Ruminant Research, 11:71-77.

Patel, A. B. ; S. Srivastava; R. S. Phadke and G. Govil (1998). Arginine activates glycolysis of goat epididymal spermatozoa: an NMR study. Biophys J., 75: 1522-1528.

Perez-Claring, R. ; J. Bermudez ; H. Anderssen and J. Burguena (1998). Influence of nutrition on testicular growth in corriedale rams during spring. Reprod. Nutr. Dev. 38(5): 529.

Piccione, G.; S. Sciano; V. Messina; S. Casella and A. Zumbo (2012): Changes in serum total proteins, proteins fractions and albumin globulins ratio during neonatal periods in kids and their mothers after parturition. Annals. Anim. Sci. 11: 249-258.

Piccione, G. ; S. Casella; C. Giannetto; I. Vazzana; P. P. Niutta and E. Giudice (2009). Influence of age on serum proteins in the calf. Acta Veterinaria Beograd 59: 413-422.

Polakoski, K. L. ; F. N. Syner and L. J. D. Zaneveld (1976). Biochemistry human seminal plasma. In: Hafez ESE (Ed.). Human Semen and Fertility Regulation in Men. St. Louis: The CV Mosby. pp. 133-143. 
Ray, K. W. ; S. L. Flamm ; A. M. Di Bisceglie and H. C. Bodenheimer (2008). Serum activity of alanine aminotransferase (ALT) as an indicator of health and disease. Hepatology, 47: 1363-1370.

Rege, J. E. ; F. Toe. ; E. Mukosa-Mugerwa; S. Tembely ; D. Anindo ; R. L. Baker and A. Lahlou-Kossi (2000). Reproductive characteristics of Ethiopian high and sheep. I. Genetic parameters of semen characteristics and their relationship with testicular measurements in ram lambs. Small Rumin. Res. 37(3):173.

Rhoads, J. M. ; X. M. Niu and S. Surendran (2008). Arginine stimulates intestinal epithelial cell migration via a mechanism requiring both nitric oxide and p70s6 k signaling. J. Nutr. 138:1652-1657.

Sacks, D. B. (2008). Carbohydrates. Tietz fundamentals of clinical chemistry, $6^{\text {th }}$ Ed., Saunders, Elsevier. PP: 390-391.

Saevre C. B. ; J. S. Caton ; J. S. Luther ; A. M. Meyer ; D. V. Dhuyvetter ; R. E. Musser ; J. D. Kirsch ; M. Kapphahn ; D. A. Redmer; and C. S. Schauer (2011). Effects of rumen-protected arginine supplementation on ewe serum-amino-acid concentration, circulating progesterone and ovarian blood flow. Sheep \& Goat Res. J. 26: 8-12.

SAS (2004). SAS User's Guide: Statistics. SAS hut., Inc., Gary, NC.

Sattler, T. and M. Fürll (2004). Creatine kinase and aspartate amino-transferase in cows as indicators for endometritis. J. Vet. Med. A. Physiol. Pathol., 51:132-137.

Srivastava S.; P. Desai ; E. Coutinho and G. Govil (2006). Mechanism of action of L.arginine on the vitality of spermatozoa is primary through increased biosynthesis of nitric oxide. Biol. Reprod. 74:95-100.

Vonnahme, K. A.; M. E. Wilson ; Y. Li ; H. L. Rupnow ; T. M. Phernetton ; S. P. Ford and R. R. Magness (2005). Circulating levels of nitric oxide and vascular endothelial growth factor throughout ovine pregnancy. J. Physiol. 565:101-109.

Wang, W. ; L. Feng ; H. Zhang ; S. Hachy ; S. Satohisa ; L. C. Laurent; M. Parast ; J. Zheng and D. B. Chen (2012). Preeclampsia up-regulates angiogenesisassociated microRNA (i.e., miR-17, -20a, and -20b) that target ephrin-B2 and EPHB4 in human placenta. J. Clin. Endoc. and Metab., 97:1051-1059.
Wu, G. and S. M. Morris (1998). Arginine metabolism: nitric oxide and beyond. Biochem. J. 336(1):1-17

$\mathrm{Wu}, \mathrm{G}$. and C. J. Meininger (2002). Regulation of nitric oxide synthesis by dietary factors. Annu. Rev. Nutr. 22:61-86

Wu, G. ; F. W. Bazer ; T. A. Cudd ; C. J. Meininger and T. E. Spencer (2004). Maternal nutrition and fetal development. J. Nutr. 134 (9) : 2169-2172

Wu, G.; F. W. Bazer ; J. M. Wallace and T. E. Spencer (2006). Board-invited review: intrauterine growth retardation: implications for the animal sciences. J. Anim. Sci. 84(9): 2316-2337.

Wu, G.; F. W. Bazer ; S. Datta ; G. A. Johnson ; P. Li ; M. C. Satterfield and T. E. Spencer (2008). Proline metabolism in the conceptus: implications for fetal growth and development. Amino Acids 35 (4) : 691702 .

Wu, G. ; F. W. Bazer ; T. A. Davis ; S. W. Kim ; P. Li ; J. M. Rhoads; M. C. Satterfield; S. B. Smith; T. E. Spencer and Y. Yin (2009). Arginine metabolism and nutrition in growth, health and disease. Amino Acids, 37: 153-168.

Wu, G.; F. W. Bazer and R. C. Burghardt (2010). Impacts of amino acid nutrition on pregnancy outcome in pigs: mechanisms and implications for swine production. J. Anim. Sci. 88:195-204.

Wu, G. ; B. Imhoff-Kunsch and A. W. Girard (2012). Biological mechanisms for nutritional regulation of maternal health and fetal development. Paediatr Perinatal Epidemiol 26 (1):4-26.

Wu, G. ; F. W. Bazer ; M. C. Satterfield; X. Li, X. ; X. Wang; G. A. Johnson; R. C. Burghardt; Z. Dai ; J. Wang and $\mathrm{Z}$. Wu (2013). Impacts of arginine nutrition on embryonic and fetal development in mammals. Amino Acids, 45: 241-256.

Yao, K. ; Y. L. Yin ; W. Y. Chu ; Z. Liu ; D. Deng ; T. Li ; R. Huang ; J. Zhang; B. Tan; W. Wang and G. Wu (2008). Dietary arginine supplementation increases mtor signaling activity in skeletal muscle of neonatal pigs. The Journal of Nutrition, 138: 867-872.

Zeitoun, M. ; A. Al-Ghoneim ; K. Al-Sobayil. and S. AlDobaib (2016). L-Arginine modulates maternal hormonal profiles and neonatal traits during two stages of pregnancy in sheep. Open Journal of Animal Sciences, 6:95-104.

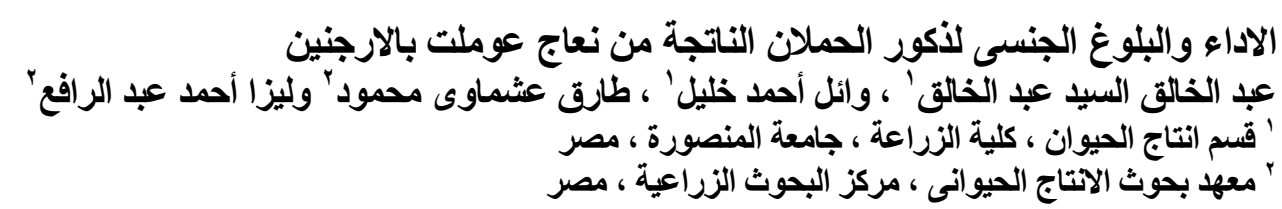

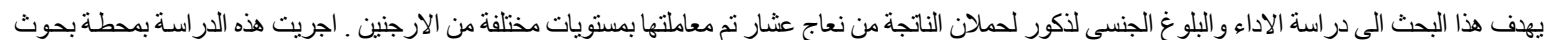

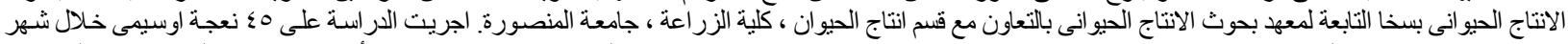

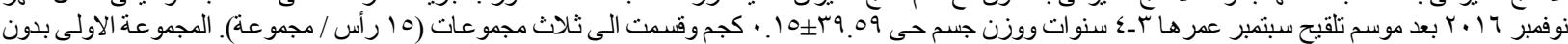

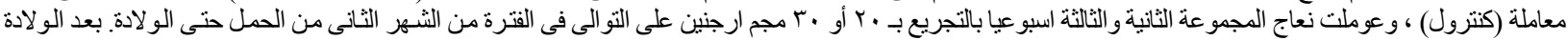

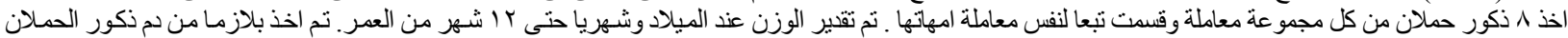

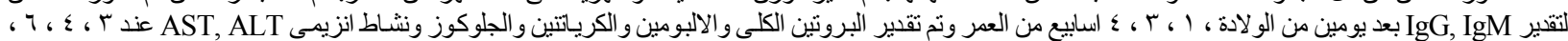

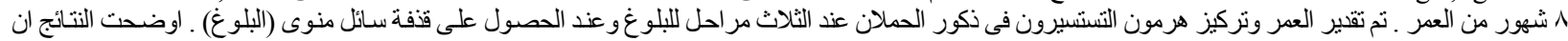

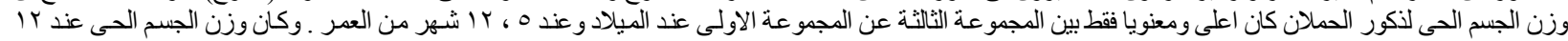

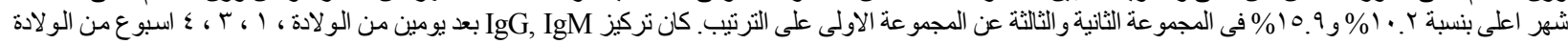

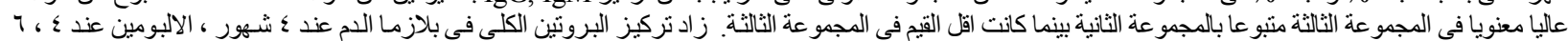

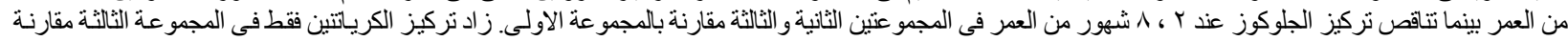

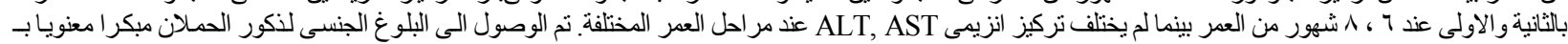

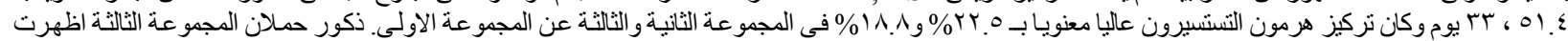

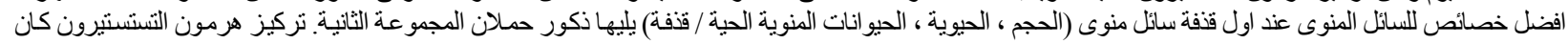

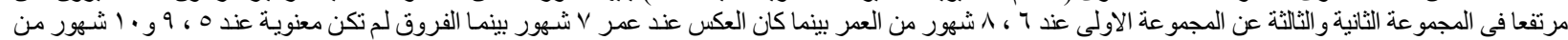

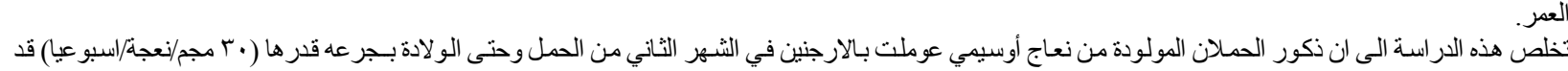

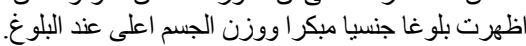

